\title{
The excavation of pit circles at Romancamp Gate, Fochabers, Moray, 1990
}

\author{
Gordon J Barclay*
}

\begin{abstract}
The excavation was undertaken with the funding and support of Grampian Regional Council to test hypotheses relating to the interpretation of cropmark pit circles: were they Neolithic or Bronze Age ceremonial or funerary structures, or were they Iron Age houses, and to what extent could the two classifications be differentiated on aerial photographs? The excavation revealed the remains of four circles (between $8.5 \mathrm{~m}$ and $11.5 \mathrm{~m}$ in diameter) of large postholes, fence lines (one with a gate), and many other pits and post-holes. Radiocarbon dates place the post circles late in the first millennium $B C$ uncal. The pit circles may be interpreted as the main structural elements of four substantial round houses, two of which burned down. Flint tools of the Mesolithic period were recovered.
\end{abstract}

\section{INTRODUCTION}

Pit circles appearing as rings of dark spots in cereal crops are usually interpreted as rings of post-holes. They have been taken to be the main structural elements of later prehistoric houses (Maxwell 1983), as free-standing rings associated with ceremonial and funerary activity (Harding 1987), and as rings of timber formerly below (or part of the structure of) second millennium BC burial mounds (cf Ashbee 1959). Tolan (1988) undertook a survey of the Scottish sites as part of a degree at the University of Newcastle upon Tyne. The research was intended to try to identify different types of circle in different situations and with different types of site in close proximity.

The next step after Tolan's survey was to try to test how well pit circles might be categorized from cropmark evidence and to begin to explore the class. Grampian Regional Council offered funds for an excavation of limited scale in their administrative area, and the site at Romancamp Gate, near Fochabers in Moray, was chosen. The site lay at the edge of a terrace of the River Spey at a height of $25 \mathrm{~m}$ above sea-level. Aerial photographs taken by RCAHMS in 1977 revealed traces of three pit circles in one field (illus 2). One was significantly larger than the others, with a scatter of other large pits around and within it, and this was chosen for excavation (illus 2, A). Its centre lay at NJ 3568 6172. A cist had been found in the field at NJ 35656166 in 1868 , less than $100 \mathrm{~m}$ away (illus 1, D).

\footnotetext{
* Historic Scotland, 20 Brandon Street, Edinburgh
} 


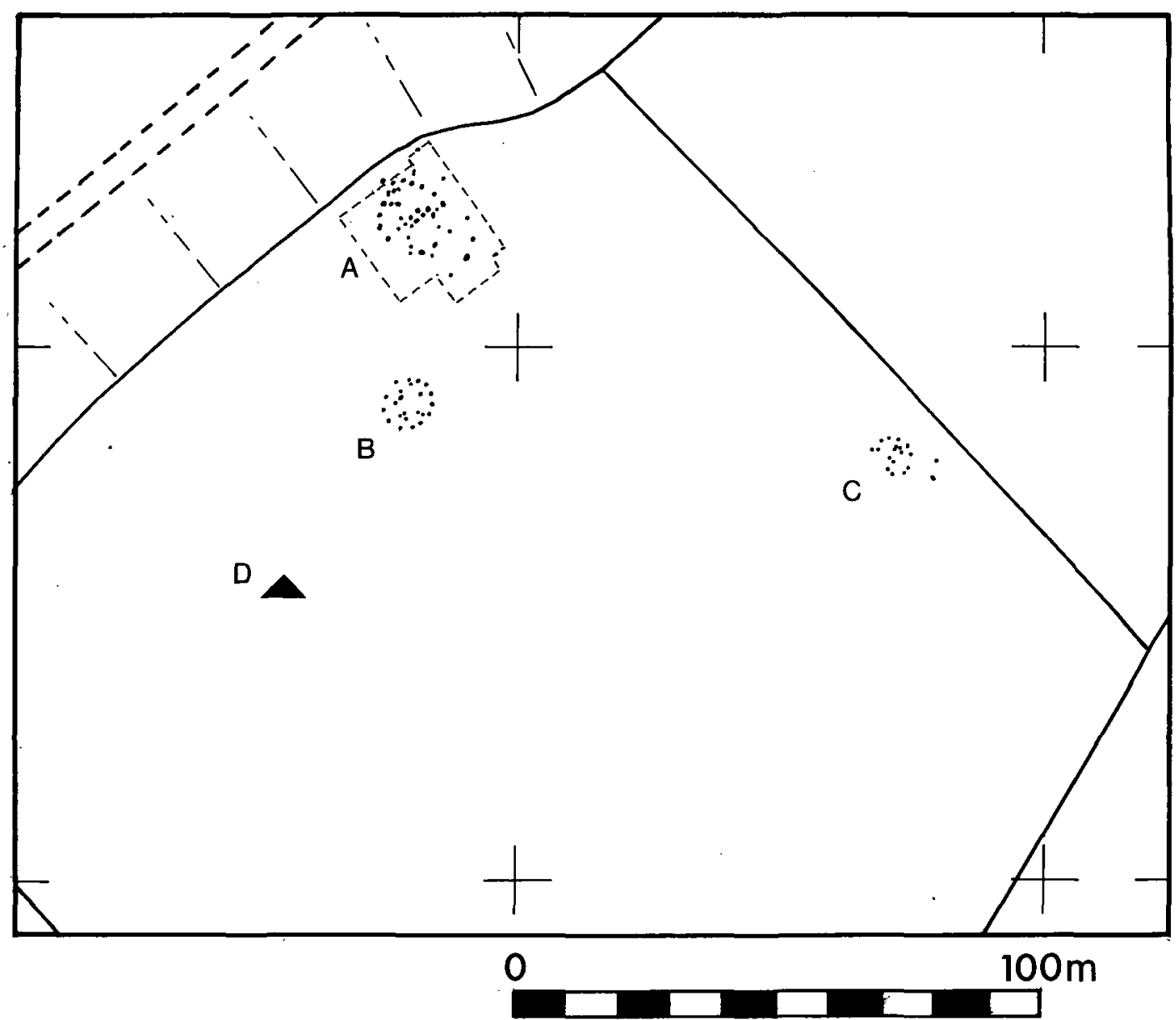

ILLUS 1 Location of the three pit circles at Romancamp Gate, from a plot prepared by the Royal Commission on the Ancient and Historical Monuments of Scotland

\section{EXCAVATION}

The excavation was undertaken over three weeks in June and July 1990. The method adopted by the author for sample excavation of cropmarks (cf Barclay \& Maxwell 1991) is to strip and clean thoroughly a relatively large area in such a way that most features, or groups of features, can be clearly delineated. A sample of features is then selected for excavation to investigate apparently typical examples from features groups, or unusual features, and to test relationships.

At Romancamp Gate a grid measuring $30 \times 25 \mathrm{~m}$ was laid out (illus 3 ). Within it an area measuring a maximum of $24 \times 25 \mathrm{~m}$ was stripped of topsoil by machine, and was hoed and trowelled. The clean subsoil surface was observed in a range of states of dampness, revealing many features by differential drying. The site was open for only three weeks; ideally the 


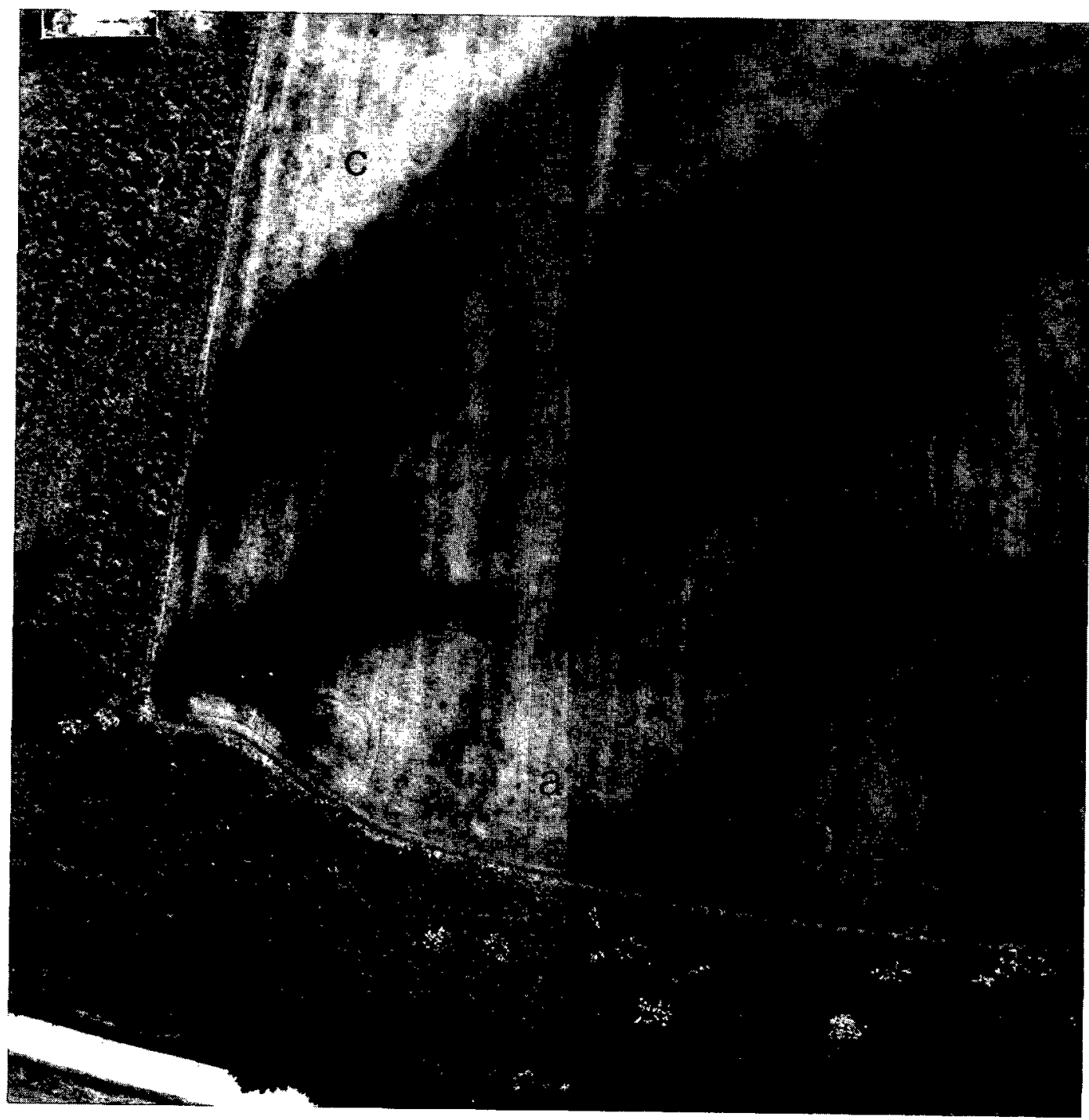

IlLus 2 Aerial photograph showing the pit circle chosen for excavation (a) and the two other pit circles (b and c). Crown copyright: RCAHMS

surface would have been left open for longer and cleaned more than once. Further features would certainly have been revealed. However, despite these limitations, over 300 separate features (mainly post-holes) were noted and planned.

There were five main groupings of features, the first four of which are identified separately on illus 3: post circles A to D and two fence lines. The remaining features could not be grouped although they may relate to the structures implied by the post rings. A collection of 31 pieces of flint (apparently of Mesolithic date) was recovered; 15 flints were from the topsoil, the rest from the fills of Iron Age features (see Saville, below). 


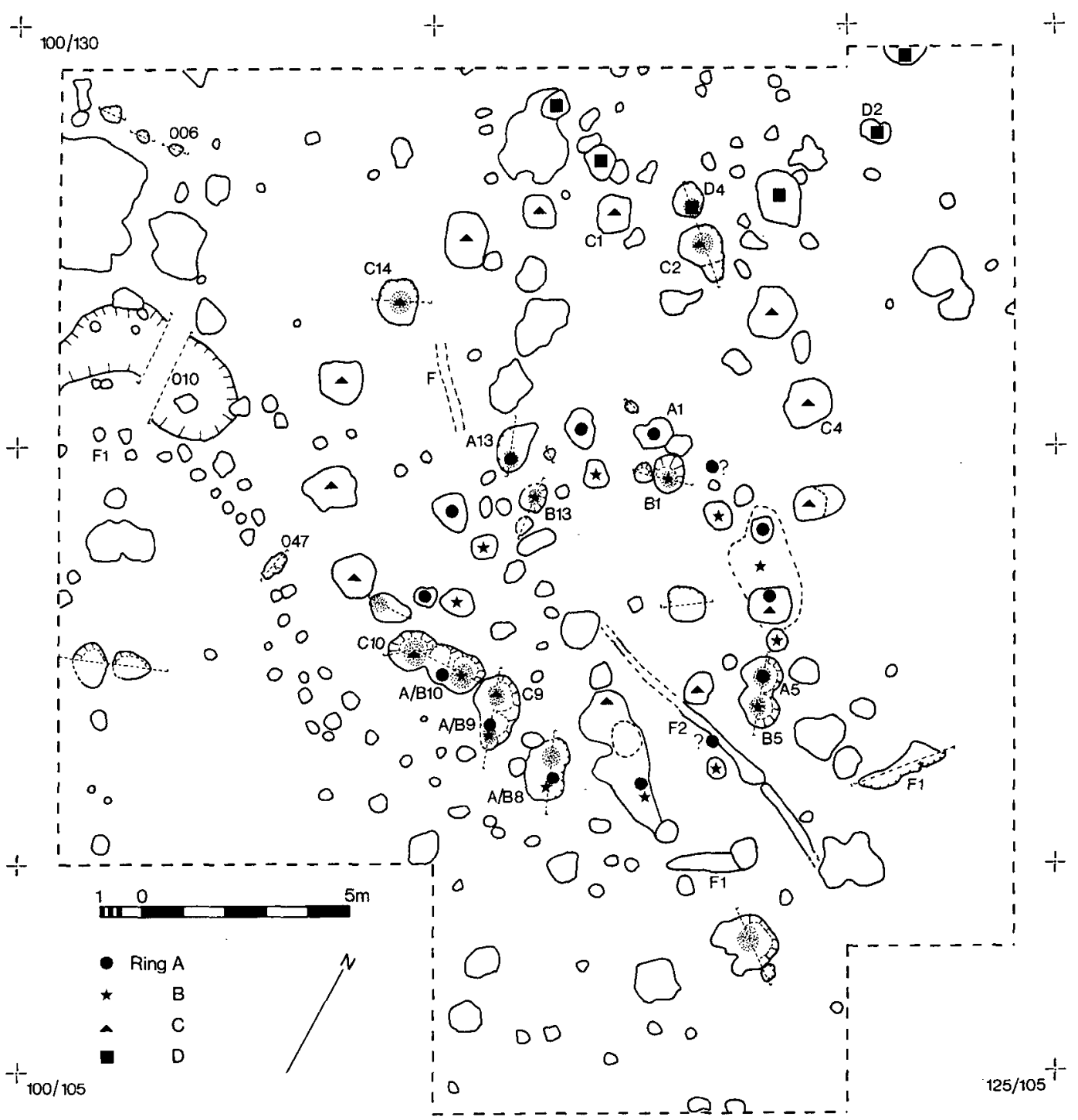

ILLUS 3 Site plan

\section{POST CIRCLE A}

The circle seems to have comprised 14 substantial posts in a ring $8.5 \mathrm{~m}$ in diameter. Only six were undisturbed (A1, A3, A11-A14). Two were not located (A2 and A6) but their probable positions were interpolated. The remaining six were to some extent disturbed by post circles $B$ and/or C. Five were investigated: A13 was the only undisturbed post-hole excavated; the others, which were dug to establish relationships, were A5 (with B5), A8 (with B8), A9 (with $\mathrm{B} 9$ and $\mathrm{C} 9$ ) and $\mathrm{A} 10$ (with $\mathrm{B} 10$ and $\mathrm{C} 10$ ). Excavation showed that ring $\mathrm{A}$ was cut by ring $\mathrm{B}$ 
(A5 cut by B5; A9 cut by B9). Charcoal from the post-pipe of A5 was radiocarbon dated (GU-3101) to $150 \pm 50 \mathrm{BC}$ uncal. A fragment of a larger smooth stone, perhaps a quern, was recovered from post-hole A13.

\section{POST CIRCLE B}

The circle comprised 14 substantial posts in a ring $8.5 \mathrm{~m}$ in diameter. Eight were undisturbed (B1, B2, B4, B6, B11-14) of which two (B1 and B13) were excavated. Four others were investigated in order to establish relationships (B5 with A5, B8 with A8, B9 with A9 and C9, B 10 with A10 and C10). Ring B cut ring A (A5 was cut by B5; A9 was cut by B9).

Of the six post-holes excavated, three showed clear evidence, in the form of substantial pieces of oak in the post-pipe, of posts burnt in situ. Charcoal from B 13 produced a radiocarbon date of $230 \pm 50 \mathrm{BC}$ uncal (GU-3100).

\section{POST CIRCLE C}

While post circles A and B were very similar in size and number of posts, circle C was very much more substantial, comprising 16 post-holes in a ring $11.5 \mathrm{~m}$ in diameter; the individual posts were $2.25-2.5 \mathrm{~m}$ apart. Two post-holes without stratigraphic relationship to other rings were investigated ( $\mathrm{C} 2$ and $\mathrm{C} 14$ ); two others with stratigraphic relationships (C9 with A9 and B9; C10 with A10 and B10) were also excavated, demonstrating clearly (in $\mathrm{C} 9$ ) that ring $\mathrm{C}$ superseded ring $\mathrm{B}$. Charcoal, from a post burnt in situ, was radiocarbon dated (GU-3103): 210 $\pm 50 \mathrm{BC}$ uncal. A smoothed stone, perhaps a whetstone, was recovered from post-hole C9.

\section{POST CIRCLE D}

At the northern edge of the excavated area six post-holes were found, the pattern of which suggested that a fourth major ring of posts, which would have been about $9 \mathrm{~m}$ in diameter, lay to the north-west of the other rings. One post-hole (D5) was excavated. In character it appeared similar to rings $A$ and $B$ but it had no stratigraphic relationship with any other rings.

\section{THE FENCE LINES}

Fence 1 is one of the most obvious features on the plan of the excavated area. Running from the south-western side of the trench, adjacent to survey point $100 / 120$, it pursues a sinuous course, curving to the south-east and then to the east, skirting the southern flank of post-rings A-C. For about half of its length two lines of posts run side by side, apparently crossing at F047, suggesting perhaps that the feature was of two phases and had been partly rebuilt. The spacing of the posts varied between $0.5 \mathrm{~m}$ and $1 \mathrm{~m}$. The line of posts terminated at a slot (at F1 in illus 3) which itself ended at a post: a similar arrangement lay $3 \mathrm{~m}$ to the north-east.

It is suggested that the posts represent a fence comprising a light superstructure set on relatively light posts, interrupted by a gate defined by two heavier posts. It is possible that the slots flanking these gate posts represent a more substantial element of the fence, perhaps planking, to withstand, for example, the pressure of stock passing through the adjacent gate. 

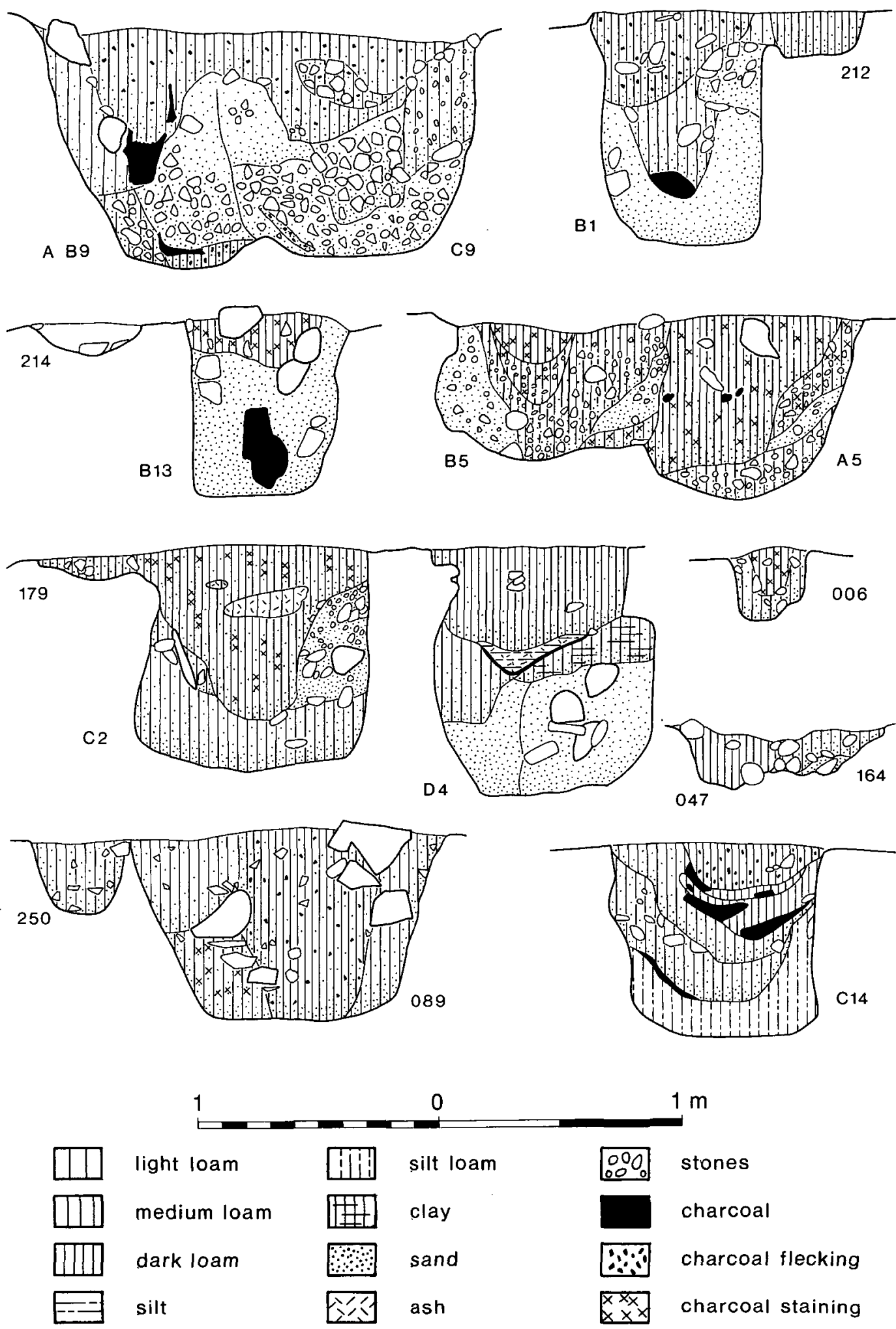

Illus 4 Sections of pit and post-holes 


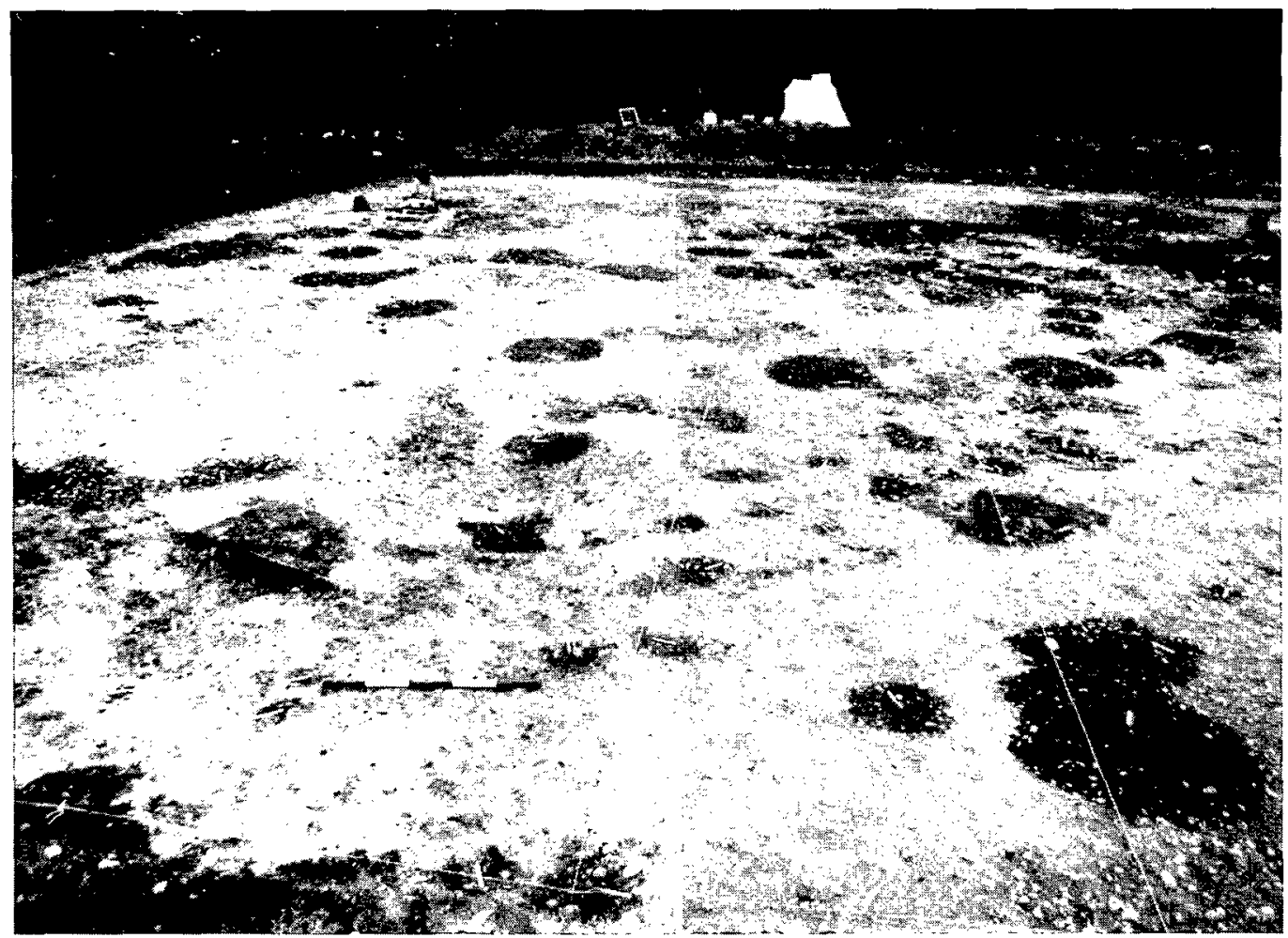

ILlus 5 Photograph of site during excavation, from the south

Fence 2, if it was a fence, was of a very different character, comprising a sporadically visible slot, surviving only to a depth of $50 \mathrm{~mm}$. The longest continuous section ran for about $7 \mathrm{~m}$ through the possible gateway in fence 1 , in a relatively straight line east to west. What may have been a continuation of this feature was noted in the area between timber rings $\mathrm{A}$ (post 13) and C (post 14).

\section{OTHER FEATURES}

Although the other post-holes and pits do not form any unambiguous patterns, there seems no reason to suppose they belong to a period markedly different to that of the circles and fence lines.

There were two hollows within the excavated area. F010 emerged from the south-west baulk. It was a shallow hollow filled with undifferentiated loam. A second hollow (F100) lay within the circuit of the three post-rings A, B and C, just to the east of features B1 and B13. It contained fragments of burnt paving. It may best be interpreted as a fragment of a floor of one of the buildings, probably one of those which had burned down. Roundwood charcoal from this hollow, probably representing occupation debris, was radiocarbon dated (GU-3102): $160 \pm 50 \mathrm{BC}$ uncal. 


\section{CHARCOAL IDENTIFICATION AND RADIOCARBON DATING}

\section{Anne Crone \& Gordon Cook}

The charcoal from the excavation was identified and assessed for dating by Dr Anne Crone (with the advice of Mr Patrick Ashmore). The selected samples were dated by Dr Gordon Cook of the Scottish Universities Research and Reactor Centre. The identifications and results are shown in Table 1.

TABLE 1

$\begin{array}{lll}\text { Lab. No. } & \text { Date Bc uncal } & \begin{array}{l}\text { Site } \\ \text { Sample }\end{array} \\ \text { GU-3100 } & \begin{array}{l}230 \pm 50 \\ \mathrm{~d}^{13} \mathrm{C}=-26.4 \%\end{array} & 25 \\ \text { GU-3101 } & \begin{array}{l}150 \pm 50 \\ \mathrm{~d}^{13} \mathrm{C}=-27.3 \%\end{array} & 19 \\ & & \\ \text { GU-3102 } & \begin{array}{l}160 \pm 50 \\ \mathrm{~d}^{13} \mathrm{C}=-26.0 \%\end{array} & 3 \\ \text { GU-3103 } & \begin{array}{l}210 \pm 50 \\ \mathrm{~d}^{13} \mathrm{C}=-25.7 \%\end{array}\end{array}$

Context

B 13 (F098) post burnt in situ.

A5 (F231) centre of post-pipe.

F100 edge; occupation material. C9 (F210) post burnt in situ.

These dates are statistically indistinguishable, whether considered in pairs or as a group. Three (those from post-holes) may be of different phases and must therefore not be combined (Ward \& Wilson 1978).

\section{REPORT ON THE FLINT TOOLS RECOVERED AT ROMANCAMP GATE}

\section{Alan Saville}

A collection of 31 pieces of flint, found in the topsoil and in the fills of Iron Age features, was submitted for specialist examination. They consist of 21 unretouched flakes (15 of which are broken), a core, a piercer, a microlith, three miscellaneous retouched pieces, and two unclassified burnt fragments (Table 2, on fiche). The core, one of the scrapers, and five of the broken flakes are also burnt. The raw material varies in colour, but all the collection appears to be the product of knapping small pebbles of beach-type flint.

The diagnostic pieces in the collection are all of Mesolithic character (illus 6), ie the microlith fragment (no 4), the scrapers (nos $5 \& 26$ ), and the microblade core (no 1). Two of the miscellaneous retouched pieces are possibly fragments of microliths (nos $14 \& 19$ ), and the third is an edge-trimmed medial blade segment (no 27), which could be an intact element of the edge of a composite tool. One of the unretouched pieces is a slender tertiary blade with the distal tip broken off (no 20). The piercer (no 3) is less diagnostic but could also be Mesolithic. None of the pieces is obviously out of character with the rest and the collection can be regarded as a potentially homogeneous one, despite the fact that almost half of the finds are from the topsoil. The typology is consistently Mesolithic, but it would be rash to assign any absolute date to such material. The scatter -31 pieces of flint from an area of 575 sq $\mathrm{m}$ - is an extremely low-level one, suggestive of the very edge of a Mesolithic knapping area or perhaps even redistribution of small numbers of flints from a concentration elsewhere. 

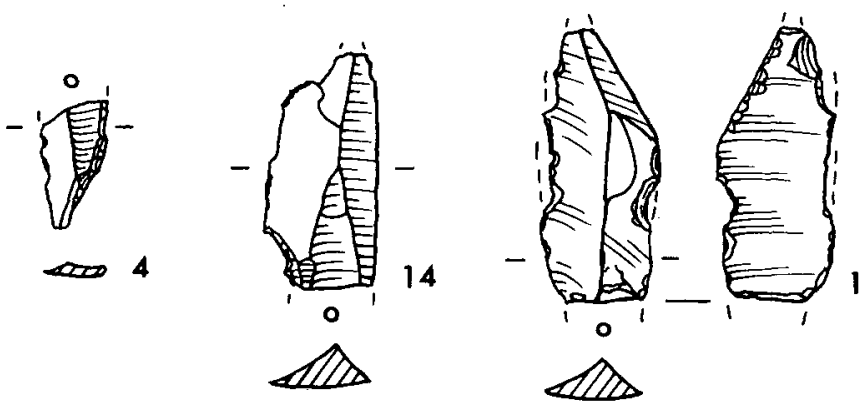

19
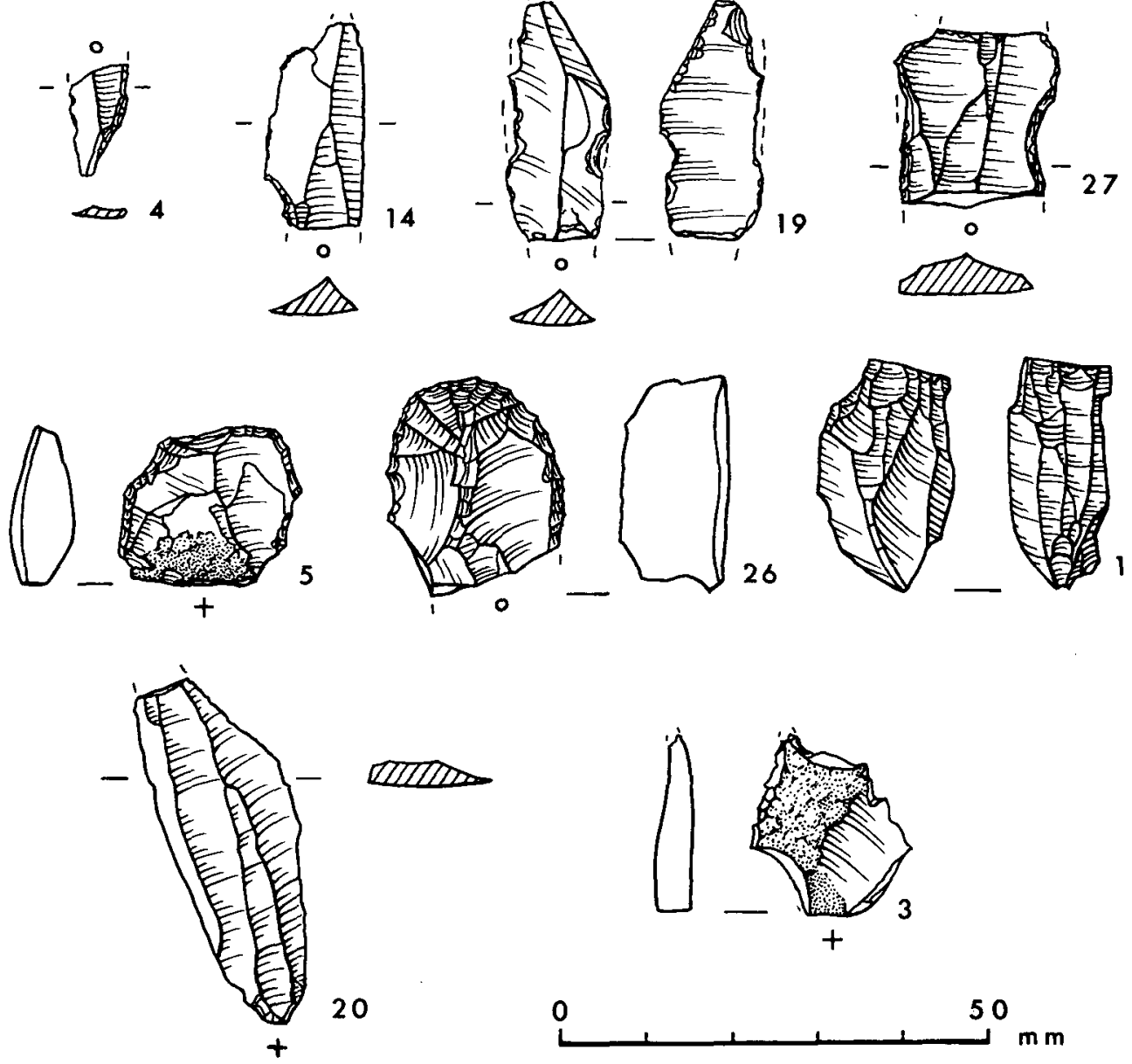

ILLus 6 Flints (illustration by Marion O'Neil)

\section{THE BOTANICAL REMAINS FROM ROMANCAMP GATE}

\section{T G Holden}

\section{SAMPLE PROCESSING}

Three samples of two litres each were taken for flotation and wet-sieving from F100 (the possible occupation layer). Flotation was carried out using a simple bucket system with 0.3 $\mathrm{mm}$ and $1 \mathrm{~mm}$ mesh sieves used for the collection of any resulting flot. Once the majority of carbonized material had been collected, any remaining material was wet-sieved through a $1 \mathrm{~mm}$ mesh. All samples were dried. The greater-than- $1 \mathrm{~mm}$ fraction for all residues and the greater-than $-0.3 \mathrm{~mm}$ fractions for all flots were then sorted with, for the flots, the aid of a low-power binocular microscope. Any items of presumed archaeological significance were removed and passed on to the appropriate specialists for comment. 


\section{THE CARBONIZED PLANT REMAINS}

The carbonized plant remains from Romancamp Gate were poorly preserved and it has therefore not been possible to identify many of them to species level. In addition to this there was evidence of some contamination by modern weed seeds, namely by members of the Chenopodaceae and Polygonaceae. These are both prolific in their seed production and rapid colonizers of disturbed ground. Their presence is probably a consequence of minor bioturbation of the deposits, or of contamination during excavation. It is not considered that this level of contamination will seriously affect interpretation of the charred plant remains.

The charred component can be divided broadly into three groups: cereals, non-cereal food plants and wild plant species.

Cereals: The cereals are represented by only three grains of barley and possibly by occasional oat grains. The latter, however, could equally well be regarded as a weedy, if tolerated, crop contaminant rather than a crop in its own right. Two of the barley grains are naked and one shows the twisted outline characteristic of a six-row variety.

Non-cereal food plants: There are several species that could be included in this category since they are known, ethnographically, to have been used as human foods. Many of them are, however, also common components of a 'natural' vegetation which is regularly associated with human settlement and their surroundings. The most obvious of these is hazel, one fragment of which was recovered from this assemblage.

Several other species in the genera Polygonum, Rumex and Chenopodium possess both edible seeds and vegetative parts (Hedrick 1972). Examples of several of these have been recovered from the gut contents of Danish bog bodies (Helbaek 1958) and from archaeological caches of seeds (Helbaek 1954). Some of these species may even have been tended as crops in their own right. Hansen (1921, cited by Steensberg pers comm), for example, highlights the traditional cultivation of this class of plant in fields on the poorer soils of Jutland as part of a system of shifting cultivation and crop rotation.

Wild plant species: Those species that have been identified to species are all typical, early colonizers of disturbed ground. They are therefore common components of wasteland vegetation and the agricultural weed flora. As such, their arrival on site and subsequent charring could be the result of incidental burning of plants growing in and around the settlement, or their being used as fuel/tinder. Similarly they could represent part of a waste fraction from crop processing, although the absence of any chaff components in the assemblage might argue against this option.

\section{DISCUSSION}

The plant remains from this site are, in general, poorly preserved. The low numbers recovered and uncertain stratigraphy and phasing of the occupations prohibit any detailed context-related interpretation. The four radiocarbon dates from the site are, however, closely grouped and the assemblage therefore provides a group of well-dated plant remains.

The site of Wardend of Durris (Russell-White 1990 and forthcoming) shows a number of similarities to Romancamp Gate with respect to the structural evidence, geographic location and period. Boardman (forthcoming) has undertaken analysis of the plant remains from this site, and, while the general pattern of a low number of components from individual 
contexts and a similar list of non-cereal taxa is evident, the dominance of hulled barley is not reflected in Romancamp Gate material. However, the general sparsity of plant remains from Romancamp Gate makes it difficult to comment on the significance of this observation in isolation. It is to be hoped that, as more well-dated plant assemblages from this region are recovered, more truly representative patterns of plant exploitation will accrue.

\section{SUMMARY}

The salient features of the assemblage are therefore:

(a) that naked six row barley is present (if represented by only two grains of certain identification);

(b) cultivated oats are possibly present though these could equally well be wild species;

(c) the non-cereal species are all typical of disturbed ground or agricultural environments. A number of species in this category may also have had economic importance in the past but the nature of this particular assemblage does not enable further comment on these aspects.

\section{SITE INTERPRETATION AND DISCUSSION}

\section{G J Barclay}

While it can be demonstrated that post-ring $A$ is superseded by $B$, which in turn is cut by the post-holes of ring $C$, no other relationships are so clear. However, if the nature of the buildings of which $\mathrm{A}, \mathrm{B}, \mathrm{C}$ and $\mathrm{D}$ are probably part is considered, then some tentative conclusions can be drawn.

Guilbert (1981; 1982) and Hill (1984) have considered the relationship between major rings of timbers and the visible and presumed walls, of slighter build, of prehistoric doublering round houses. Hill argued that the distances of the main timber ring and that of the wall from the centre of a circular house is governed by the ratio 1:0.707, for sound structural reasons. He tested this against the plans of a large number of round houses, and while many cluster round this ratio (Hill 1984, Fig 2) a number are significantly different.

The two large round houses excavated in the fort and palisaded sites at Bannockburn (Rideout pers comm; Tavener 1987) both had extant wall lines but also an unusual external post-ring. The house in the palisaded enclosure was of two phases: one wall was $14.8 \mathrm{~m}$ in diameter, the other $15.5 \mathrm{~m}$. The internal post-ring was $10.4 \mathrm{~m}$ across (ratios 1:0.670; 1:0.703). In the fort, the wall of the house was $14.4 \mathrm{~m}$ in diameter, the post-ring $11 \mathrm{~m}$ (ratio 1:0.764). Nearby, at West Plean (Steer 1956) revealed the plan of a house ('house 2') with a wall $11.3 \mathrm{~m}$ in diameter surrounding a post-ring $6.4 \mathrm{~m}$ in diameter (ratio 1:0.56). If the Romancamp Gate rings represent similar structures, then it can be suggested that the largest ring $(\mathrm{C}-11 \mathrm{~m}$ in diameter) was part of a house between $15 \mathrm{~m}$ and $16.5 \mathrm{~m}$ in diameter, and the small rings (A, B and D) of houses some $12 \mathrm{~m}$ to $12.7 \mathrm{~m}$ in diameter.

Illus 7 shows likely wall lines for the four buildings, based on a ratio of 1:0.7. It is already clear that $\mathrm{A}, \mathrm{B}$ and $\mathrm{C}$ did not coexist. However, a house based on ring $\mathrm{D}$ could have coexisted with one based on rings $A$ or $B$. The fences could not have coexisted with ring $C$ or ring $B$, but could have with a ring $D$ house and, just possibly, with ring $A$, even though in the 


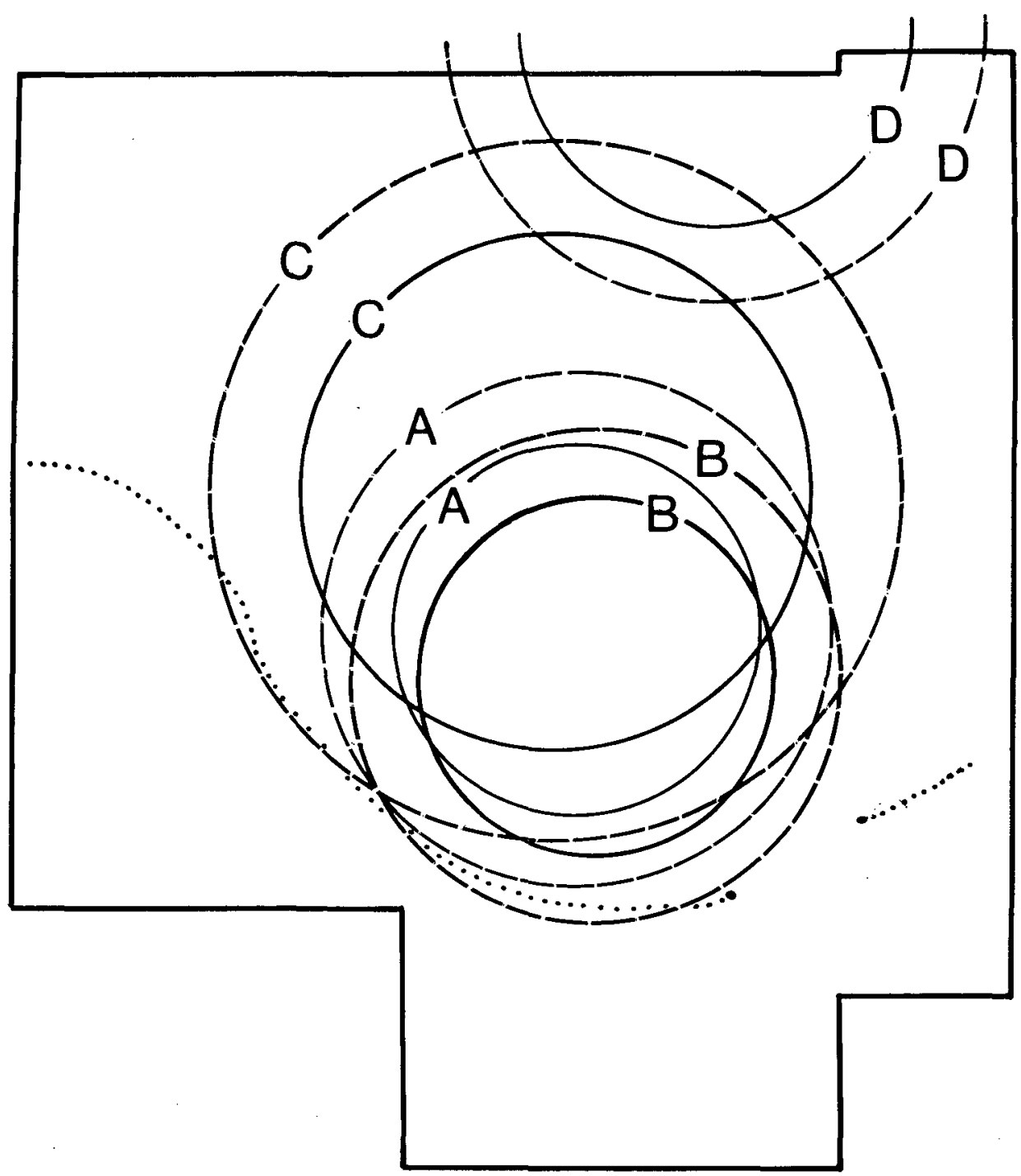

ILlus 7 Interpretative diagram showing the circles of pits (solid lines) and the likely location of the associated walls; the dotted line shows the position of fence 1

last cases the position of the gate in fence 1 might be considered inconvenient. The radiocarbon evidence provides a close cluster of dates between 100 and $300 \mathrm{BC}$ uncal but does not allow separate phases of activity to be differentiated.The stratigraphy on site showed that ring $A$ had been cut by ring $B$, which had in turn had been cut by ring $C$. The clustering of the radiocarbon dates suggests that we have a sequence of three houses, built one after the other, with evidence for the second and third having burnt down.

There are no excavated parallels for the structures in the area. Activity dated by radiocarbon to the late first millennium BC uncal was located at Cullykhan (Greig 1971) along 
the coast to the east, where 'Phase I' activity was dated to $387 \pm 65 \mathrm{BC}$ uncal (BM-446) and $397 \pm 59 \mathrm{BC}$ uncal (BM-639), and a burnt layer on the knoll on which the massive gate structure lay was dated to $106 \pm 51 \mathrm{BC}$ uncal (BM-443). At Wardend of Durris, Kincardineshire (Russell-White 1990 and forthcoming) excavation revealed structures superficially similar to some of those at Romancamp Gate.

The greatest concentration of pit rings discussed by Tolan (1988) lies to the west of Romancamp Gate, in the arable area around Inverness. Some, such as Lonnie 1 (Tolan 1988, number 10: NH 734 487) which has a broad halo around the pits, perhaps representing a sunken floor (cf Douglasmuir: Kendrick 1982), may be comparable. Others, such as Ballagan (Tolan 1988, number 3: NH 794 525) at $18 \mathrm{~m}$ diameter, are clearly not the remains of domestic structures of the kind investigated at Romancamp Gate; nor probably are pit circles such as Lonnie 2 (Tolan 1988, number 11) where the ring of pits, $7.5 \mathrm{~m}$ in diameter, has a 'wall' line around it c $16 \mathrm{~m}$ in diameter, a ratio of 1:0.47.

The collection of plant material adds little to our overall knowledge of later prehistoric cereals in Scotland, but in the context of the limited evidence of Iron Age houses in the area the botanical evidence at least provides some new information on the presence of two cereals and that of a range of possible non-cereal food plants. The Mesolithic use of the area was attested only by the small assemblage of flint; none of the excavated features suggested anything other than a late prehistoric date.

\section{CONCLUSIONS}

The excavation of Romancamp Gate provides the first evidence of Iron Age settlement in a non-defensive context in this part of Scotland, highlighting the extraordinary gaps which still exist in our knowledge of the basic forms and chronology of the settlement of much of the country. Only the site at Wardend of Durris, almost $80 \mathrm{~km}$ to the south-south-east, offers any parallels. Consequently the results of the excavation reported here must remain largely in a vacuum until the Iron Age of the region is further explored.

\section{ACKNOWLEDGEMENTS}

My first thanks must go to the owner of the land, the Crown Estate Commissioners, to Miss Lambert, their agent with Smiths Gore, and to Mrs Young, the tenant of Den Farm, for permission to excavate, and to Grampian Regional Council for funding the work. I am very grateful to Myra Tolan, my co-director, and to Ian Shepherd, the Regional Archaeologist, for their considerable help. My thanks also to Maite Etcheberry, Jim Inglis and Sarah Ritson for their work throughout the excavation and to Leckie Shepherd, John Cruse, Margaret Jubb and Graham Steele for their help at weekends, and to Ian Keillar for his support and hospitality. Finally, I would like to express my particular thanks to Historic Scotland for their support for my research and for agreeing to date four radiocarbon samples as part of their programme with SURRC.

\section{REFERENCES}

Ashbee, P 1959 'Stake and post circles in British round barrows', Archaeol J, 114. (1959), 1-9.

Barclay, G J \& Maxwell, G S 1991 'The excavation of a long mortuary enclosure within the Roman fortress at Inchtuthil', Proc Soc Antiq Scot, 121 (1991), 27-44. 
Boardman, $\mathrm{S}$ forthcoming 'The charred plant remains', in Russell-White, C J (ed) 'The excavation of a Neolithic and Iron Age settlement at Wardend of Durris, Kincardine and Deeside, Grampian Region'.

Greig, J C 1971 'Excavations at Cullykhan, Castle Point, Troup, Banffshire', Scott Archaeol Forum 3 (1971), 15-21.

Guilbert, G 1981 'Double-ring roundhouses, probable and possible, in prehistoric Britain', Proc Prehist Soc, 47 (1981), 299-317.

Guilbert, G 1982 'Post-ring symmetry in roundhouses at Moel y Gaer and some other sites in prehistoric Britain', in Drury, P J (ed) Structural Reconstruction, 67-86.

Hansen, H P 1921 Fra gamle dage 1. Herning: Forfatterens Forlag.

Harding, A 1987 Henge monuments and related sites of Great Britain. Air photographic evidence and catalogue. Oxford. (=Brit Archaeol Rep Brit Ser, 175.)

Hedrick, U P 1972 Sturtevant's edible plants of the world. New York.

Helbaek, H 1954 'Prehistoric food plants and weeds in Denmark: a survey of archaeological research 1923-1954', in Iverson, J (ed) Essays in Honour of Knud Jessen. Danmarks Geologiske Undersogelse, ser IV, 3(6), 250-61.

Helbaek, H 1958 'Grauballemandens Sidste Maltid', KUML 1958, 83-116.

Hill, P H 1984 'A sense of proportion: a contribution to the study of double-ring roundhouses', Scott Archaeol Rev 3, pt 2 (1984), 80-6.

Kendrick, J 1982 'Excavations at Douglasmuir 1979-1980', in Harding, D (ed) Later Prehistory in South-East Scotland, Edinburgh, 136-40.

Maxwell, G S 1983 'Recent aerial survey in Scotland', in Maxwell, G S (ed) 1983 The Impact of Aerial Reconnaissance on Archaeology, C B A Research Report, 49, London, 27-40.

Russell-White, C J 1990 'Excavations at Wardend of Durris, Kincardine \& Deeside District', Historic Scotland, Archaeological Operations and Conservation: Annual Report 1989, 23-6.

Russell-White, C J forthcoming 'The excavation of a Neolithic and Iron Age settlement at Wardend of Durris, Kincardine and Deeside District, Grampian Region'.

Steer, K A 1956 'An early Iron Age homestead at West Plean, Stirlingshire', Proc Soc Antiq Scot, 49 (1955-6), 227-51.

Tavener, N 1987 'Bannockburn: The Homestead' in Central Excavation Unit and Ancient Monuments Laboratory Annual Report 1987. Edinburgh.

Tolan, M 1988 Pit Circles in Scotland: Some Possible Interpretations Dissertation presented to the Department of Archaeology, University of Newcastle upon Tyne.

Ward, G K \& Wilson, S R 1978 'Procedures for comparing and combining radiocarbon age determinations: a critique', Archaeometry, 20 (1978), 19-32.

This paper is published with the aid of grants from Historic Scotland and from Grampian Regional Council 